\title{
RISK OF LEAD INTOXICATION IN EXPOSED WORKERS
}

Tanja P. Kuneva,

Diana B. Apostolova,

Zlatka B. Stoyneva,

Aneta B. Ivanova, Vladimira V. Boyadzhieva, Kristina A. Yosifcheva

Clinic of Occupational Diseases, University Hospital "St. Iv. Rilski", Sofia

\begin{abstract}
Summary
A clinical observation of 15 workers exposed to lead, engaged in recycling of lead accumulators, was carried out. The exposition to lead aerosols varied from 2 months to 14 years. High levels of lead absorption and excretion after application of antidote therapy were found in all workers followed up. There were no manifestclinical signs and symptoms in 7 workers whom we suspected to be lead carriers. Anemia was diagnosed in 8 of the investigated persons. Severe form of intoxication, including paresis of both radial nerves, was established in one worker. Subacute lead poisoning, presenting with lead colic, anemia, toxic hepatitis and toxic polyneuropathy, was diagnosed in three persons with only several months of intensive lead exposure. Association between lead exposure, metal absorption and clinical symptoms in investigated persons were discussed.
\end{abstract}

Key words: risk, lead intoxication, antidote therapy

\section{Introduction}

Automotive batteries are usually lead-acid, made from electrodes containing lead and lead dioxide, immersed in electrolyte containing sulphuric acid. Failure to comply with the requirements for their manufacturing, use, storage or recycling makes them hazardous to health and the environment. Automotive batteries are subject to almost complete recycling $-80 \%$ of the lead and lead compounds contained in them can be used for the manufacture of new batteries $[1,2]$. In the EU legislation related to waste particular attention is paid to batteries and accumulators $[3,4]$.

There are about 400 sites for collection of unusable batteries and accumulators in Bulgaria. Accumulator batteries are recycled in Kardzhali, Montana and Plovdiv. An increasing number of private companies get involved in recycling, and some fail to comply with the legal requirements regarding such activities.

The study aimed to determine the risk of lead intoxication in workers engaged in companies for recycling lead batteries. 


\section{Material and Methods}

Monitoring was conducted on a group of 15 employees of different companies admitted to Toxicology Department at the Clinic of Occupational Diseases of St. Ivan Rilski University Hospital - Sofia, during the period 2010-2014, on the occasion of established elevated blood lead values after preventive examinations conducted or because of demonstrated symptoms of lead effect.

The average age of the men studied was $42.47 \pm 11.26$ years (age range $24-59$ ). The period of exposure to lead aerosols varied between 2 months and 14 years, the average length of service being $6.44 \pm 5.47$ years.

All the patients were given physical and neurological examinations and the following laboratory investigations were ordered:

hematological: complete blood count with differential count, reticulocyte count (RE) and basophilic punctate/stippled erythrocytes (BPE);

biochemical: creatinine, liver enzymes (AST, ALT and GGT), serum iron;

indicators of porphyrin metabolism (deltaaminolevulinic acid / 5-ALA / in urine, ALA dehydratase (5-ALA-D) and free erythrocyte protoporphyrin (EPP);

tests for toxic chemicals: concentrations of lead in blood $(\mathrm{PbB})$ and lead in urine $(\mathrm{PbU})$ before and after the antidotal therapy with $1.0 \mathrm{~g}$ $\mathrm{CaNa}_{2}$ EDTA; by indications - abdominal ultrasound scan and neuro-EMG.

The measurement of lead in blood and urine was performed by flame atomic absorption spectrometry (AAS)"Analyst 400", "Perkin Elmer". Haematological investigations were made using automatic hematology analyzer Sysmex KX21N. Free erythrocyte protoporphyrin was determined by the method of Mauzerall and Granick - ion-exchange chromatography columns [5]. Biochemical tests were determined at the automatic clinical chemistry analyzer Cobas Integra 400.

Variance and correlation analyses were used for statistical processing of data.

\section{Results}

The toxic chemical studies we performed demonstrated high lead absorption and excretion in all workers followed up after applying antidotal therapy (Figure 1). There were no workers with plumbemia within the reference range (up to $1.19 \mu \mathrm{mol} / \mathrm{l}$ ). Content of $\mathrm{PbB}$ exceeding biological limits for exposed persons $(1.2-1.92 \mu \mathrm{mol} / \mathrm{l})$ was found in one worker; acceptable lead absorption in blood (1.93-2.88 $\mu \mathrm{mol} / \mathrm{l})$ was present in 7 workers, and "excessive" absorption of over $2.88 \mu \mathrm{mol} / 1$ - in the remaining 7 workers. In 4 of these latter, the absorption was more than $3.68 \mu \mathrm{mol} / \mathrm{l}$ ).

After application of antidotal treatment with

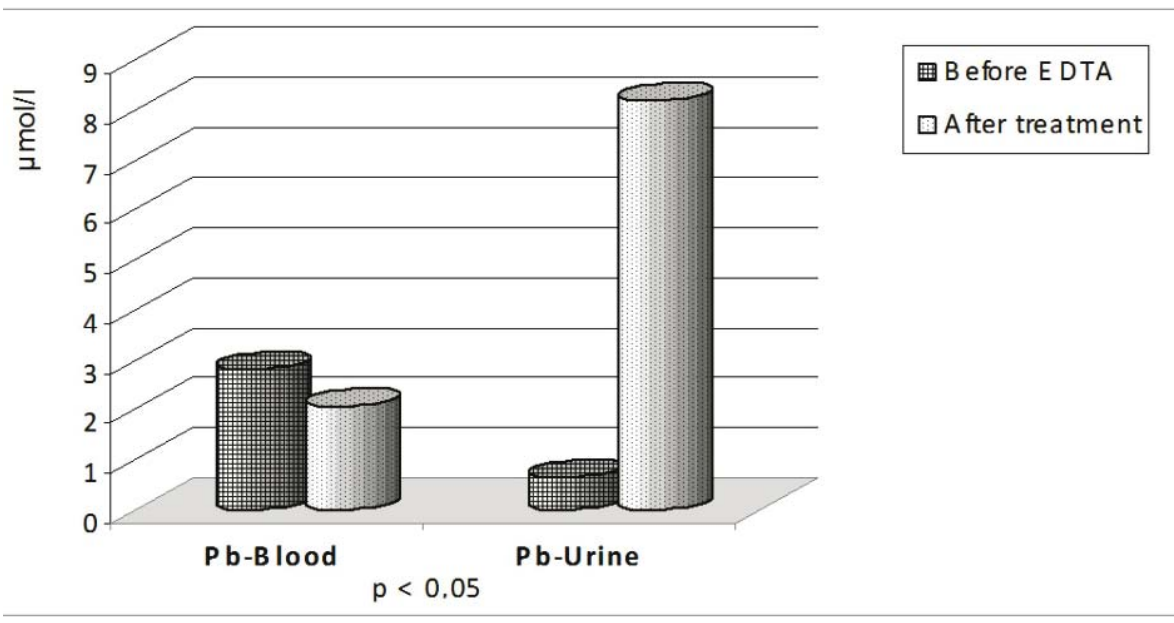

Figure 1. Levels of $\mathrm{Pb}$ in blood and urine before and after $\mathrm{CaNa}_{2} \mathrm{EDTA}$ treatment 
$1.0 \mathrm{~g}$ of $\mathrm{CaNa}_{2} \mathrm{EDTA}$, the lead excretion in urine increased sharply from baseline average levels of $0.64 \pm 0.36$ up to $8.18 \pm 3.96 \mu \mathrm{mol} / 1$ (with the highest value of $14.82 \mu \mathrm{mol} / \mathrm{l}$ ) (Table 1 ).

Against the background of high lead absorption and excretion in the workers examined, abnormalities in porphyrin metabolism were found, manifested by a decrease in the activity of 5-ALA-D, increase in erythrocyte protoporphyrin, increase of 5-ALA in urine and decrease of hemoglobin values (Table 2).

Table 1. Concentration of $\mathrm{Pb}$ in blood and urine $(\mu \mathrm{mol} / \mathrm{l})$ in exposed persons before and after $\mathrm{CaNa}_{2} \mathrm{EDTA}$ antidote therapy

\begin{tabular}{lllll}
\hline $\begin{array}{l}\text { Indicators } \\
(\mu \text { mol } / 1)\end{array}$ & $\begin{array}{l}\mathrm{Pb} \mathrm{B} \\
\text { before }\end{array}$ & $\begin{array}{l}\mathrm{Pb} \mathrm{B} \\
\text { after treatment }\end{array}$ & $\begin{array}{l}\mathrm{Pb} \mathrm{U} \\
\text { before }\end{array}$ & $\begin{array}{l}\mathrm{Pb} \mathrm{U} \\
\text { after treatment }\end{array}$ \\
\hline Average & 2.81 & 2.06 & 0.64 & 8.18 \\
\hline $\mathrm{SD}$ & 0.77 & 0.52 & 0.36 & 3.95 \\
\hline Max & 4.38 & 2.91 & 1.43 & 14.82 \\
\hline Min & 1.2 & 1.41 & 1.06 & 0.6 \\
\hline
\end{tabular}

Table 2. Levels of DALA-D, DALA, EPP, Hb, RE, BPE and Fe in the workers' blood

\begin{tabular}{llllllll}
\hline Indicators & $\begin{array}{l}\mathrm{ALA}-\mathrm{D} \\
\mu \mathrm{mol} / \mathrm{min} / \mathrm{E} \mathrm{Er}\end{array}$ & $\begin{array}{l}\mathrm{EPP} \\
(\mu \mathrm{mol} / \mathrm{L} / \mathrm{Ery})\end{array}$ & $\begin{array}{l}\mathrm{Hb} \\
(\mathrm{g} / \mathrm{L})\end{array}$ & $\begin{array}{l}\mathrm{RE} \\
(\%)\end{array}$ & $\begin{array}{l}\mathrm{BPE} \\
(\%)\end{array}$ & $\mathrm{Fe}(\mu \mathrm{mol} / \mathrm{l})$ & $\begin{array}{l}\text { DALA } \\
\text { urine } \\
\mu \mathrm{mol} / 24 \mathrm{~h}\end{array}$ \\
\hline Average & 8.5 & 16.6 & 135.8 & 12.3 & 0.00 & 20.8 & 67.48 \\
\hline SD & 4.8 & 20.1 & 20.6 & 23.3 & 0.01 & 13.6 & 46.7 \\
\hline Max & 13.3 & 67.3 & 160 & 81 & 0.02 & 55 & 165 \\
\hline Min & 2.5 & 3.6 & 88 & 0.2 & 0 & 8 & 6 \\
\hline $\begin{array}{l}\text { Reference } \\
\text { values }\end{array}$ & $17.5-46.5$ & to 1.1 & $\begin{array}{l}140- \\
180\end{array}$ & $0.2-2.0$ & 0 & $11-28$ & $11.4-57.2$ \\
\hline
\end{tabular}

\section{Discussion}

The most commonly used biomarker for current lead exposure is the concentration of lead in blood [6-10]. Tell et al. [11] found a close correlation [coefficient of correlation $\mathrm{R}=0.86$, $\mathrm{p}$ $<0.001]$ between the level of lead in blood of 20 lead-exposed workers and their urinary excretion of lead for 24 hours after intravenous infusion of $1.0 \mathrm{~g} \mathrm{CaNa}_{2}$ EDTA and found that chelation therapy resulted in changes of lead content mainly in blood and soft tissues, while the lead content in the skeleton, where most of the metal is accumulated, was only partly influenced by the therapy.

The sharp increase of plumburia after application of antidote is the result of its extraction from body depots. It is known that greatest quantities of lead accumulate in bones, followed by liver, kidney, skeletal muscles, brain and other organs $[12,13]$. EDTA treatment lead to formation of a chelate complex with the lead and resulted in increased excretion in the urine, clinical picture improvement, reduction of EPE and gradual normalization of other lead biomarkers (Pb-B, ALA-D, ALA-U $[14,15]$.

It has been proven that lead distorts hemoglobin biosynthesis and iron utilization by inhibiting 5-ALA-D, resulting in a growth of 5ALA in urine and inhibiting ferrochelatase, comprising the iron in the porphyrin ring and formation of hemoglobin, and causing the increase of free erythrocyte protoporphyrin (EPP). As a result of these disorders, sideroachrestic type of anemia with compensatory reticulocytosis and basophilic punctate/stippled erythrocytes in the peripheral blood have been reported $[6,16]$ According to some authors, chemosynthesis disorders, evidenced by the increase of EPP, occurs when lead concentration in blood is higher than 40 $\mu \mathrm{g} / \mathrm{dl}[17]$.

Anemia saturnina was diagnosed in 8 of the persons tested, which manifested by decreased values of hemoglobin, reticulocytosis. In three of them, basophilic stippled erythrocytes were found.

In connection with the direct effects of lead on 
hepatocytes with changes in liver function and development of toxic hepatitis [18], as well as because of its excretion by the kidneys and possible toxic nephropathy [19], we tested serum transaminases and creatinine in exposed workers. The average levels for the whole group were within the reference range, but in four of the workers, biochemical and ultrasonographic evidence of toxic hepatitis were established.

In three workers a complex syndrome was observed, characterized by toxic hepatitis, lead colic, anemia and toxic polyneuropathy. Given the brief intense lead exposure for a few months, we assumed that it was a sub-acute lead intoxication.

In one of the workers with 2 years of lead exposure, a severe intoxication was found, including excessive lead absorption of 3.87 $\mu \mathrm{mol} / \mathrm{l}$; excretion of lead upto $14.88 \mu \mathrm{mol} / \mathrm{l}$; encefalo-myelo-polyneuropathy, with bilateral paresis of the radial nerve and impossibility for extension of both hands -"pendulous wrists" type, expressed anemia and toxic hepatitis.

In seven of the workers there were no expressed clinical symptoms and we assumed that it concerned a high-grade and risk lead carrying.

Four workers were discharged, diagnosed with mild chronic lead intoxication, exhibited by high levels of lead in the blood and urine, reduced DALA-D (ALA-D), increased erythrocyte protoporphyrin, increased excretion of urinary ALA (ALA-U), expressed anemia, reticulocytosis, and liver function disorders.

In recent years the only lead intoxications we observed have been namely in such proceedings.

\section{Conclusions}

The study conducted in a group of workers engaged in recycling of lead acid batteries and exposed to lead, showed no direct correlation between the length of service and the risk of lead intoxication development.

The clinical signs of chronic saturnism we observed in the workers depended not only on the metal absorption and excretion magnitude but also on the individual reactivity of the body.

Due to the failure to comply with safety requirements in accumulator recycling companies, there is a serious risk for workers' health and development of lead intoxication.

\section{References}

1. Regulation on batteries and accumulators and unusable batteries and accumulators, CM Decree № 351 of 27.12 .2012 (prom., SG No. 2 of 8.01.2013, effective from 8.01.2013, amended, No. 6 of 22.1.2013, amended and suppl., SG No. 51 of 11.06.2013, effective from 11.06.2013). Bulgarian.

2. Management of discarded batteries and accumulators. INFRABILD - Stroiteli [Internet]. 2012 [cited 2014 Oct 12];VI(7) [about 1 p.]. A v a i l a b l e f r o m : http://stroiteli.elmedia.net/sti/bg/20127/editorials/ 8 02202.html, Bulgarian.

3. Directive $200 \overline{6} / 66 /$ EC of the European Parliament and of the Council on detailed rules for the calculation of recycling efficiency of the recycling processes of waste batteries and accumulators.

4. Directive 2000/53/ EC of the European Parliament and of the Council of 18.09.2000 on disused vehicles.

5. Mauzerall D, Granick S. The occurrence and determination of ALA and PBG in urine. J Biol Chem. 1958;219:435-46.

6. Zapryanov Z. Lead. In: Kaloyanova F, editor. Hygienic Toxicology vol. 3. Sofia: Meditzina i Fizkultura; 1983.p. 9-22. Bulgarian.

7. Georgieva P, Tsalev D. Lead levels in blood, nails and teeth as biomarkers of exposure informational value and relevance. Bulgarian Journal of Chemistry. 2013;2(4):133-44. Bulgarian.

8. Gordon JN. Taylor A. Bennett PN. Lead poisoning: case studies. $\mathrm{Br} \mathrm{J}$ Clin Pharmacol. 2002;53(5):451-8.

9. Skerfving S, Bergdahl IA. Lead. In: Nordberg G, Fowler B, Nordberg M, Friberg L, editors. Handbook on the Toxicology of Metals. 3rd ed. NY: Academic Press; 2007. p. 599-643.

10. Sommar JN, Svensson MK, Björ BM, Elmståhl SI, Hallmans G, Lundh $\mathrm{T}$, et al. End-stage renal disease and low level exposure to lead, cadmium and mercury; a population-based, prospective nested case-referent study in Sweden. Environ Health. 2013;12:9.

11. Tell I, Somervaille LJ, Nilsson U, Bensryd I, Schutz A, Chettle DR, et al. Chelated lead and bone lead. Scand J Work Environ Heath. 1992;18(2):113-9.

12. Crinnion WJ. EDTA redistribution of lead and cadmium into the soft tissues in a human with a high lead burden - should DMSA always be used to follow EDTA in such cases? Altern Med Rev. 2011;16(2):109-12.

13. Xu Y, Wang Y, Wang L, Zhao M, Zhang X, et al. Lead detoxification activities of a class of novel DMSA-amino acid conjugates. Chem Res Toxicol. 2011;24(6):979-84. 
14. Ogawa M, Nakajima Y, Kubota R, Endo Y. Two cases of acute lead poisoning due to occupational exposure to lead. Clin Toxicol. 2008;46(4):332-5.

15. Petracca M, Scafa F, Boeri R, Flachi D, Candura SM. Imported occupational lead poisoning: report of four cases. Med Lav. 2013;104(6):428-33.

16. Kuneva T. Lead poisoning and compounds. In: Kostova V, Petkova V, editors. Occupational diseases. Sofia: Ral-kolobar; 2007. p. 33-38. Bulgarian.
17. LaDou Joseph. Occupational \& Environmental Medicine. 4th ed. McGraw-Hill Companies, Inc. 2007.

18. Labudda M. Lead hepatotoxicity: selected aspects of pathobiochemistry -Med Pr. 2013;64(4):565-8. Polish.

19. Weaver VM, Griswold M, Todd AC, Jaar BG, Ahn $\mathrm{KD}$, Thompson CB, et al. Longitudinal associations between lead dose and renal function in lead workers. Environ Res. 2009;109(1):101-7 